March 31, 1952 (pp. $55+10$ pl. ; Manchester : Central Library, 1952), records a slight decrease in the total issue of nearly six million volumes, continuing the trend in the adult lending libraries since the general increase in the cost of books enforced a reduction in the purchase of several copies of a popular book. The photographic reproduction service is in such demand that many requests from beyond the confines of the City have had to be declined. The value of this service has been demonstrated most effectively in the 'Technical Library, which has its own photographic equipment. The report indicates the way in which this Library is being developed in the closest possible liaison with the various specialist libraries and industrial organizations, and the value of such technical library service is now becoming recognized by industrial firms. Its seating capacity is taxed to the utmost, and although the total issue of items was 186,095 compared with 186,014 in the previous year, the number of books issued on request at the counter again increased in all subjects, especially in technology. The trade catalogue collection now exceeds ten thousand items, nearly six thousand of which were consulted during the year-an increase of 50 per cent. Stress is laid on the assistance given to readers by the staff of both the Technical Library and the Commercial Library and Information Department. In view of the approaching centenary of the Manchester Public Libraries, a chronological table from the purchase of the first building, the Hall of Science, Campfield, on June 10, 1850, is included with the report.

\section{Large-volume Measuring-Flasks}

Messrs. H. J. Elliotr, Ltd., E-Mil Works, Treforest Trading Estate, Nr. Pontypridd, Glam., state that from time to time they receive inquiries from laboratories in Great Britain and abroad for measuringflasks of 3,5 and 10 litres capacity; the maximum capacity generally available is only 2 litres. Their present information is that the demand would be limited to about a dozen of each size per annum, which would scarcely justify the expense of obtaining the necessary moulds. Scientific workers interested are invited to write to Messrs. H. J. Elliott, to assist the firm in deciding whether to undertake the production of measuring-flasks of large capacity.

\section{Nuffield Foundation Gerontological Research Fellowship}

Tне Nuffield Foundation, as part of its programme for the care of old people, is offering a research fellowship, of professorial status, for research on the scientific aspects of ageing, or alternatively one or more fellowships of less senior status. The award(s) may be tenable at any university in the United Kingdom and is open to applicants of either sex, usually not more than forty-five years of age. The senior fellowship will normally be made for a period of five years, renewable for five more years, and will be worth not less than $£ 2,000$ a year plus superannuation and child allowance; research expenses will be met by the Foundation, including provision for research assistants, apparatus and technicians. If, instead of this appointment, one or more fellowships of a lower category are awarded, they will be for three years in the first instance and worth $£ 1,000$ $£ 1,500$ a year plus superannuation, child allowance and research expenses. Application forms, to be returned before June 1, and further information can be obtained from the Secretary, Nuffield Foundation, Nuffield Lodge, Regent's Park, London, N.W.1.

\section{Sixth International Congress of Microbiology}

THE Sixth International Congress of Microbiology will be held in Rome during September 6-12, 1953, under the presidency of Prof. V. Puntoni, director of the Institute of Hygiene, University of Rome, with Prof. E. Biocca, director of the Institute of Parasitology, University of Rome, as secretary-general. The following is a provisional list of the sections into which the Congress will be divided : general microbiology (morphology, metabolism, growth factors, etc.); growth inhibitors (antibiotics, chemotherapeutics, antiseptics); genetics; pathogenicity (virulence, toxins); microbiological technique and diagnosis (large-scale production of micro-organisms, quantitative microbiology, etc.) ; general immunology ; immunological chemistry; animal viruses; plant viruses; bacteriophages; rickettsiæ; schizomycetes ; spirochætes ; fungi ; protozoa ; microbetransmitting arthropods; microbiology applied to human, veterinary and plant pathology; microbiology applied to agriculture; industrial microbiology and fermentations; microbiology applied to hygiene; and microbiology of milk and foodstuffs. Since the preliminary programme was prepared, the Organizing Committee has decided to establish a sub-section on bacterial taxonomy. All those wishing to read papers must send in titles and abstracts (not exceeding five hundred words) before April 30. In connexion with the Congress the Istituto Superiore di Sanita is planning six symposia, at which the lectures will be by invitation only. The symposia will be on the following subjects : bacterial cytology; microbial metabolism; nutrition and growth factors; growth inhibitors and chemotherapy; morphology, biology and systematics of the Actinomycetales; and host-virus interactions. Further information can be obtained from the VI Congresso Internazionale di Microbiologia, Istituto d'Igiene "G. Sanarelli", Citte Universitaria, Roma.

Faraday Society: Fiftieth Anniversary and Hundredth General Discussion

THe fiftieth anniversary celebrations and the one hundredth general discussion of the Faraday Society will be held in the Royal Institution (21 Albemarle Street, London, W.I) during April 16-18 under the presidency of Prof. H. S. Taylor, dean of the Graduate School, Princeton University. The programme for April 16 will consist of addresses by two foundermembers, Prof. F. G. Donnan and Sir James Swinburne; an address by Sir Harold Hartley on "Michael Faraday as a Physical Chemist"; the seventh Spiers Memorial Lecture, on "Models and Molecules", by Prof. J. H. Hildebrand (University of California); and a guest-night dinner at the Dorchester Hotel to commemorate the fiftieth anniversary of the Society. During April 17-18 there will be a general discussion on "Equilibrium Properties of Solutions of Non-Electrolytes", in which the equilibrium properties of liquid mixtures (general theory and experimental) and solubility (gaseous mixtures and liquid mixtures) will be considered. Application for attendance at these meetings must be made by March 22. Application forms and further information can be obtained from the Secretary of the Society, 6 Gray's Inn Square, London, W.C.1.

\section{Third International Biometric Conference}

ThE third international biometric conference, arranged by the Biometric Society, a Section of the International Union of Biological Sciences, will be held 